\title{
PENENTUAN KEBUTUHAN PERSEDIAAN OBAT GENERIK DENGAN METODE MATERIAL REQUIRMENT PLANING DAN MODEL OPTIMASI PADA LOGISTIK FARMASI DI RUMAH SAKIT DELIMA ASIH KARAWANG
}

\author{
Muhamad Sayuti ${ }^{1}$, Sitti Aminah Haddade ${ }^{2}$, Dicky Suryapranatha ${ }^{3}$, Karya Hidayat ${ }^{4}$ \\ 1,3,4 Jurusan Teknik Industri, Fakultas Teknik dan Ilmu Komputer, Universitas Buana Perjuangan Karawang \\ Jl. HS. Ronggowaluyo Telukjambe Timur Karawang, \\ 2, Jurusan Magister Teknik Industri, Universitas Islam Indonesia, Yogyakarta \\ Jl. Jalan Kaliurang km. 14,5 Sleman Yogyakarta 55584 \\ Email: muhamad.sayuti@ubpkarawang.ac.id
}

\begin{abstract}
This study discusses the effect of pharmaceutical logistics management on drug inventory management in hospitals to optimize drug planning and inventory in hospitals. It is important for hospitals to manage drug supplies because of the nature of the drugs in this study, which are often used, so inventory must be controlled to avoid running out of drugs or stockouts. The method used in this research is Material Requirement Planning (MRP) to determine the demand for generic drugs supply optimization model with Mixed Integer Linear Programming (MILP) and Sensitivity Analysis. The results of this study are pharmaceutical logistics management at the Delima Asih Hospital, Karawang, there is still a shortage of drugs so that the hospital takes action in urgently purchasing drugs to third parties at a higher cost. Control of drug supply at the Delima Asih Hospital has not met the need for drug supplies, as seen from the 10 generic drugs studied and 3 of them have run out, namely Ethambutol $500 \mathrm{Mg}$ (-827 pcs), Pyrazinamide $500 \mathrm{Mg}$ (-513 pcs), Simvastatin $20 \mathrm{Mg}$ (-141 pcs). pcs), and the side is stagnant. The MRP method and the optimization model become one of the proposals in inventory control where the results of both calculations have met the need for drug supplies at the Delima asih Hospital, Karawang.
\end{abstract}

Keywords: Pharmaceutical Logistics Management; Material Requirements Planning; Mixed Integer Linear Programming; Medicine

\begin{abstract}
ABSTRAK
Penelitian ini membahas tentang pengaruh manajemen logistik farmasi terhadap pengelolaan persediaan obat di rumah sakit untuk mengoptimalkan perencanaan dan persediaan obat di rumah sakit. Rumah sakit penting melakukan pengelolaan persediaan obat karena sifat obat pada penelitian ini yang sering digunakan maka persediaan harus terkontrol untuk menghindari kehabisan obat atau stockout. Metode yang digunakan dalam penelitian ini adalah Material Requirement Planning (MRP) untuk mengetahui permintaan persediaan obat generik model optimasi dengan Mixed Integer Linear Programming (MILP) dan Analisis Sensitivitas. Hasil dari penelitian ini adalah manajemen logistik farmasi di RS delima asih karawang masih terjadi kekurangan obat sehingga pihak rumah sakit mengambil tindakan dalam pembelian obat secara urgensi ke pihak-3 dengan biaya lebih besar. Pengendalian persediaan obat di RS delima asih belum memenuhi kebutuhan persediaan obat dengan dilihat dari 10 obat generik yang diteliti dan 3 diantaranya mengalami kehabisan yaitu Ethambutol $500 \mathrm{Mg}$ (-827 pcs), Pyrazinamide $500 \mathrm{Mg}$ (-513 pcs), Simvastatin $20 \mathrm{Mg}$ (-141 pcs), dan sisianya mengalami stagnan. Motode MRP dan model optimasi menjadi salah satu usulan dalam pengendalian persediaan dimana hasil dari peritungan keduanya telah memenuhi kebutuhan persediaan obat di RS Delima Asih Karawang.
\end{abstract}


Kata kunci: Manajemen Logistik Farmasi; Perencanaan Kebutuhan Material; Pemrograman Linier Integer Campuran; Obat

\section{PENDAHULUAN}

Sebagai industri pelayanan jasa kesehatan, rumah sakit memerlukan sebuah manajemen pengelolaan agar dapat berjalan sesuai dengan visi dan misi yang dijalankan. Menurut (Pinna et al., 2015) Manajemen logistik merupakan bagian dari supply chain management yang merencanakan, mengimplementasikan, dan mengendalikan efesiensi dan efektifitas suatu aliran barang dari titik asal sampai titik konsumsi dalam permintaan untuk memenuhi kebutuhan pelanggan. Persedian obat yang terlalu besar maupun terlalu sedikit akan membuat rumah sakit megalami kerugian. Kerugian tersebut dapat berupa biaya persedian obat yang membesar serta terganggunya kelancaran pelayanan kesehatan di rumah sakit.

Rumah sakit delima asih karawang merupakan sebuah rumah sakit swasta milik PT. Sisma Medika Internasional yang bergerak di bidang pelayanan kesehatan. Rumah sakit deliama asih karawang berdiri pada tahun 2007 di karawang. Rumah sakit delima asih karawang memiliki 7 fasilitas medis dimana salah satunya adalah instalasi farmasi yang menyediakan barang farmasi yaitu obat.

Saat ini rumah sakit delima asih karawang masih mengalami kendala dalam hal kebijakan persediaan. Penangan persediaan obat dilakukan berdasarkan kebijakan dari pihak manajemen instalasi farmasi. Pemesanan obat dilakukan apabila jumlah persedian obat di gudang sudah sedikit atau hampir habis tanpa memperhitungkan jumlah obat yang dipesan dan komponen - komponen biaya yang akan mempengaruhi total biaya persedian. Jumalah obat yang dipesan oleh rumah sakit hanya berdasarkan jumlah pemesanan sebelumnya. Selain itu, rumah sakit delima asih karawang belum melakukan penetapan perioritas penanganan terhadap obat-obat yang ada di instalasi farmasi dan penentuan jumlah cadangan pengaman yang harus di sediakan leadtime yang telah ditentukan supplier. Ketidakmampuan merencanakan dengan baik persediaan ini membuat rumah sakit mengalami terjadinya persedaiaan yang berlebih (over stock) dan kehabisan obat (stock out) sehingga berpengaruh terhadap total biaya persedian obat. Kelibihan obat dan kekurangan obat tersebut dikarnakan jumlah obat permintaan dan persedian yang tidak seimbang akibat dari kurang tepatnya dalam penentuan jumlah persedian sehingga menyebabkan biaya yang dikeluakan rumah sakit cukup besar.

Untuk mengatasi permasalahan tersebut, rumah sakit delima asih karawang perlu melakukan pengendalian persedian. Tujuan dari pengendalian persedian tersebut pada tingkat optimal agar proses atau kegiatan pelayanan kesehatan di rumah sakit dapat berjalan dengan lancar dan biaya persediaan tidak terlalu besar.

Pengaturan persedian obat pada suatu instalasi atau rumah sakit sangat dibutuhkan untuk memenuhi pesanan dalam jumlah dan waktu yang tepat sehingga biaya total persedian dapat dikurangi dengan adanya periode pesan dan kuantitas pemesanan yang optimal. Pemesanan dalam jumlah yang tepat dan waktu yang tepat akan mengurangi terjadinya kelebihan persedian sehingga rumah sakit dapat melakukan pengelolaan persediaan dengan baik dan memenuhi kebutuhan di rumah sakit.

Oleh karena itu, pada penelitian ini akan dilakukan pengendalian persedian dengan menghitung jumlah obat yang akan dipesan dengan perhitungan matematis dan model optimasi untuk menentukan kebijakan persedian obat yang tepat untuk mengurangi terjadinya persedian obat yang berlebih dan kekurangan sehingga meminimalisir total biaya persediaan obat yang akan dikeluarkan. Pengendalian persediaan tersebut menggunakan metode material requirement planning dan model optimasi dengan Mixed Integer Linear Programming pada lingo 11.0 dikarnakan output dari perhitungan ini adalah jumlah kebutuhan obat untuk periode berikutnya.

\section{Rumusan Masalah}

Rumusan masalah penelitian ini diantaranya sebagai berikut:

Bagaimanakah penerapan manajemen logistik obat di Instalasi Farmasi Rumah Sakit Delima Asih Karawang? 
Apakah pengendalian persediaan obat pada Rumah Sakit Delima Asih Karawang telah memenuhi kebutuhan rumah sakit?

Metode apakah yang dapat di pakai dalam pengendalian persediaan obat generik di Instalasi Farmasi Rumah Sakit Delima Asih Karawang?

\section{METODE PENELITIAN}

\section{Data dan Informasi}

Data yang digunakan dalam penelitian ini berupa data kuantitatif yaitu data pemakaian obat generik tahun 2019, data persedian obat generik, alus proses logistik rumah sakit, dan data informasi obat generik.

\section{Teknik Pengumpulan Data}

Teknik yang digunakan dalam penelitian ini yaitu dengan melakukan pengamatan langsung melalui observasi, wawancara dan dokumentasi pada bagian rumah sakit, khususnya bagian instalasi farmasi, serta sejumlah informasi yang terkait, untuk mendapatkan informasi yang akurat dan lengkap yang berhubungan dengan penelitian ini.

\section{Teknik Analisa Data}

Teknik analisa data pada penelitian ini, terdapat tahapan-tahapan dalam analisis data dimulai dari proses alur logistik rumah sakit, penentuan kebutuhan obat dengan metode Material Requirement Planning (MRP) dan model optimasi lingo 11.0, dan kemudian di analisa dengan analisis sensitivitas.

\section{Manajemen Logistik Farmasi Rumah Sakit}

Menurut Febriawati (2013), Manajemen logistik farmasi rumah sakit merupakan bagian proses supply chain yang berfungsi untuk merencanakan, melaksanakan, dan mengendalikan ke efisienan dan efektifan aliran penyimpanan barang, pelayanan dan informasi terkait dari titik permulaan (point of origin) hingga titik konsumsi (point of consumption) dalam tujuannya untuk memenuhi kebutuhan pelanggan di rumah sakit. (The council of logistics management).

\section{Metode Material Requirement Planning (MRP)}

Material Requirements Planning adalah menghitung kebutuhan material untuk produksi berdasarkan jenis jumlah, dan waktu material yang dibutuhkan. Perhitungan MRP diturunkan dari perencanaan produksi atau, (Master Production Schedule). Kemudian dijabarkan menjadi kebutuhan material pembentukannya. (Martono, 2015). Input utama merupakan komponen dasar MRP yang terdiri dari:

\section{Master Production Schedule}

Merupakan suatu pernyataan defenitif tentang produk akhir (end item) apa yang direncanakan perusahaan untuk diproduksi, beberapa kuantitas yang dibutuhkan, pada waktu kapan dibutuhkan, bilamana produk itu akan diproduksi.

\section{Bill of Material}

Merupakan daftar kuantitas komponen, bahan-bahan, dan bahan material yang diperlukan untuk menciptakan suatu produk.

\section{Inventory Master File}

Sistem MRP harus memiliki dan menjaga suatu data persedian yang up to date untuk setiap komponen barang, data ini harus menyediakan informasi yang akurat tentang ketersediaan komponen seluruh transaksi persediaan, baik yang sudah terjadi maupun yang akan direncanakan.

\section{Model Optimasi Lingo11.0}

Formulasi model akan digunakan untuk pengambilan keputusan dalam merencanakan kebutuhan obat periode berikutnya dangan jangka waktu yang panjang dan jumlah sesuai dengan kebutuhan persediaan obat generik di RS Delima Asih Karawang. Formulasi model model disusun berdasarkan atas model yang dikembangkan oleh Hakim \& Ulfah, (2019). Berikut ini model yang dikembangkan dengan kondisi nyata dan ketersedian data dilapangan.

\section{a. Batasan}

Jumlah total periode sudah diketahui. 1 periode $=1$ bulan.

Biaya dalam semua periode dianggap tetap dan tidak tergantung pada jumlah yang dipesan.

Biaya kekurangan persediaan diatasi dengan kehilangan penjualan.

Permintaan obat sudah diketahui. 


\section{b. indeks}

i : jenis obat $\mathrm{A}(\mathrm{i}=1, \ldots, 10)$

t : jangka waktu $(\mathrm{t}=1, \ldots, \mathrm{t})$

o : periode order (to $=1, \ldots$, o)

c. parameter

$\mathrm{a}_{\mathrm{i}} \quad$ : Biaya penempatan order

hi : Holding cost obat $i$

$\mathrm{S}_{\mathrm{i}} \quad$ : Kapasitas gudang untuk obat $i$

$\mathrm{ss}_{\text {it }} \quad$ : Safty Stock untuk obat $i$ pada periode $t$

$\mathrm{d}_{\text {it }} \quad$ : permintaan untuk obat i pada periode $t$

$\mathrm{Y}_{\text {ito }}:\{1,0\}$ - biner variabel

1 : Pemesanan obat $i$ untuk periode $t$, pada periode pesanan $o$

0 : Tidak pemesanan obat $i$ untuk periode t, pada periode pesanan $o$

$\mathrm{Q}_{\text {ito }}$ : Jumlah obat yang datang pada periode $t$ dan memerintahkan pada periode $o$

$\mathrm{X}_{\mathrm{it}} \quad$ : awal obat $i$ tingkat persediaan pada periode $t$

\section{c. Fungsi Tujuan}

Minimasi total biaya persedian obat

$$
\text { Min }=\sum_{t=1}^{10} \sum_{t=l i+1}^{t} \sum_{t^{\prime}=1}^{t-l i} a_{i} Y_{i t o}+\sum_{i=1}^{10} \sum_{t=l i+1}^{t} \sum_{o=1}^{t-l i}\left(h_{i} Q_{i t t^{\prime}}\right)+h_{i} X_{i t}
$$

\section{d. Kendala}

\begin{tabular}{|c|c|}
\hline $\mathrm{X}_{\mathrm{it}}=\mathrm{X}_{\mathrm{it}}+\sum_{\mathrm{t}=\mathrm{li}+1}^{\mathrm{t}-\mathrm{li}} \mathrm{Q}_{\mathrm{ito}}-\mathrm{d}_{\mathrm{it}}$ & $\forall i ; \forall t ; \forall o$ \\
\hline $\mathrm{X}_{\mathrm{it}} \geq \mathrm{SS}_{\mathrm{it}}$ & $\forall i ; \forall t$ \\
\hline $\mathrm{Q}_{\text {ito }} \leq \mathrm{Y}_{\text {ito }}$ & $\forall i ; \forall t ; \forall o$ \\
\hline$\sum_{i \in\left(1_{n, m, 10)}\right.} X i t+\sum_{i \in\left(1_{1, m} 10\right)} \sum_{t^{\prime}=1}^{t-l i} Q_{i t o} \leq \mathrm{S}_{1}$ & $\forall i ; \forall t ; \forall o$ \\
\hline$Y_{\text {ito }}=\left\{\begin{array}{l}\perp \\
0\end{array}\right.$ & $\forall i ; \forall t ; \forall o$ \\
\hline$\in Z+$ & $\forall i ; \forall t ; \forall o$ \\
\hline$\in Z+$ & $\forall i ; \forall t ; \forall \forall$ \\
\hline$\in Z+$ & $\forall i ; \forall t$ \\
\hline$\in Z+$ & $\forall i ; \forall t$ \\
\hline
\end{tabular}

Kendala (2) Menyatakan total permintaan obat pada periode sebelumnya harus memenuhi permintaan dan menentukan nilai tingkat persediaan awal $\left(\mathrm{X}_{i l}\right)$. Kendala (3) Menyatakan Persedian awal tidak harus kurang dari jumlah yang ditentukan oleh safety stock. Kendala (4) untuk mendefinisikan $Y_{\text {itt' }}$ yaitu keputusan yang tergantung pada $Q_{\text {ito }}$ berarti bahwa ketika ada pesanan periode $o$, Yito $=1$ dan memenuhi persamaan $\mathrm{Y}_{\text {ito }}$ dan $\mathrm{Q}_{\text {ito. Kendala (5) Menyatakan bahwa jumlah }}$ obat-obatan tidak boleh melebihi kapasitas penyimpanan. Kedala (6) keputusan biner $\mathrm{Y}_{\text {ito }}$ nomor 1 mewakili pemesanan obat dan 0 tidak menempatkan pesanan. Kendala (7) menyatakan bahwa variabel biner $\mathrm{Q}_{\text {ito }}$ adalah harus lebih besar dari 0 ini juga berlaku pada variabel $\mathrm{Y}_{\text {ito. }}$ Kendala (8) variabel $X_{\text {it }}$ dalam kendala (9), variabel $Z_{\text {it }}$ dalam kendala (10). Setelah membuat formulasi model matematis selanjutnya diaplikasikan menjadi bahasa pemograman Lindo Lingo 11.0.

\section{Analisis Sensitivitas}

Analisis sensitivitas merupakan analisis yang dilakukan pada solusi optimal suatu persolan program linear karna adanya perubahan parameter untuk melihat berapa besar perubahan dapat ditolerir sebelum solusi optimal mulai kehilangan optimalitasnya. Program linear merupakan suatu metode penyelesaian untuk memperoleh solusi optimal (maksimum/minimum) dari suatu persoalan. (Fernando \& Najid, 2017). 


\section{Prosedur Penelitian}

Adapun tahapan-tahapan dalam proses penelitian digambarkan sebagai berikut:

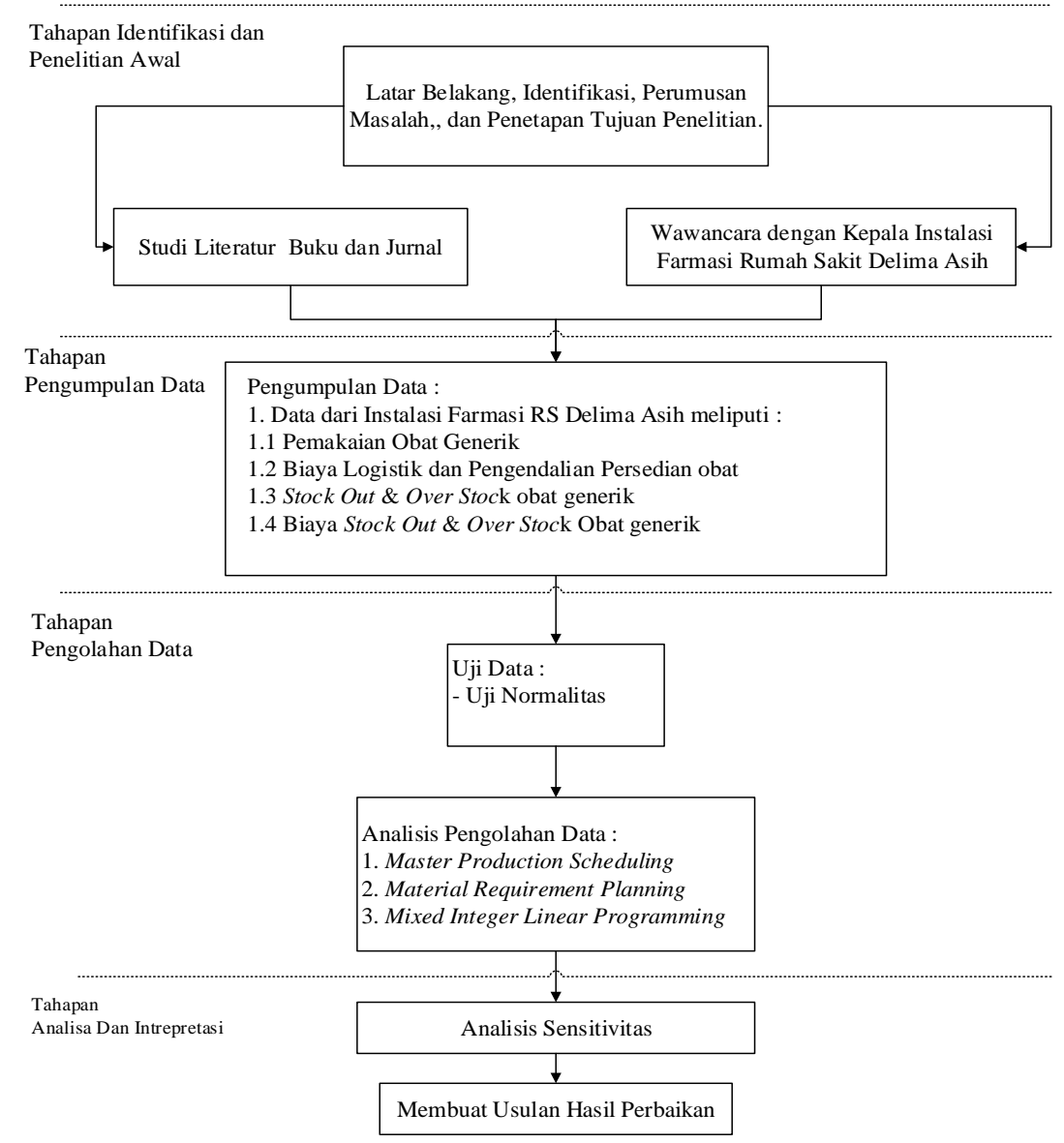

Gambar 1. Prosedur Penelitian

Sumber: Penulis, 2020

\section{HASIL DAN PEMBAHASAN}

Berikut merupakan data pemakaian obat generik di Rumah sakit Delima Asih karawang periode Januari 2019 sampai dengan Desember 2019:

Tabel 1. Data Pemakaian Bahan Baku Material

\begin{tabular}{clccccccccccccc}
\hline No & $\begin{array}{l}\text { Nama Obat } \\
\text { Generik }\end{array}$ & Jan & Feb & Mrt & Apr & Mei & Juni & Juli & Agst & Sept & Okt & Nov & Des & $\begin{array}{c}\text { Jumlah } \\
\text { Pemakaian }\end{array}$ \\
\hline 1 & $\begin{array}{l}\text { Metformin } \\
\text { 500 Mg }\end{array}$ & 7494 & 6610 & 6274 & 5833 & 5842 & 1247 & 6161 & 5274 & 2824 & 4183 & 2681 & 1858 & 56281 \\
2 & $\begin{array}{l}\text { Paracetamol } \\
\text { 500 Mg }\end{array}$ & 3341 & 4569 & 6515 & 5207 & 4010 & 3771 & 3610 & 3770 & 3464 & 3245 & 3640 & 3866 & 49008 \\
3 & $\begin{array}{l}\text { Vitamin B12 } \\
\text { 50 Mcg }\end{array}$ & 2106 & 2444 & 2768 & 2232 & 1630 & 1278 & 1755 & 1354 & 1142 & 1351 & 1458 & 1728 & 21246 \\
4 & $\begin{array}{l}\text { Asam } \\
\text { Mefenamat }\end{array}$ & 1278 & 1294 & 2350 & 3063 & 1504 & 1621 & 1646 & 1550 & 1362 & 2127 & 1957 & 1787 & 21539 \\
& $\begin{array}{l}\text { 500 Mg } \\
\text { Dexamethas } \\
\text { one O.5 Mg } \\
\text { Ibuprofen } \\
\text { 400 Mg }\end{array}$ & 850 & 985 & 1338 & 1165 & 765 & 479 & 1042 & 1147 & 1039 & 776 & 806 & 777 & 11169 \\
\hline
\end{tabular}




\begin{tabular}{lllllllllllllll}
\hline 7 & $\begin{array}{l}\text { Ethambutol } \\
\text { 500 Mg }\end{array}$ & 378 & 300 & 238 & 247 & 139 & 113 & 982 & 974 & 361 & 517 & 511 & 395 & 5155 \\
8 & $\begin{array}{l}\text { Pyrazinamid } \\
\text { e 500 Mg }\end{array}$ & 470 & 435 & 349 & 372 & 289 & 105 & 1057 & 883 & 327 & 155 & 143 & 270 & 4855 \\
9 & $\begin{array}{l}\text { Allopurinol } \\
\text { I00 Mg }\end{array}$ & 457 & 250 & 662 & 339 & 532 & 137 & 520 & 158 & 460 & 394 & 354 & 212 & 4475 \\
10 & $\begin{array}{l}\text { Simvastatin } \\
\text { 20 Mg }\end{array}$ & 24 & 183 & 127 & 32 & 15 & 53 & 169 & 109 & 194 & 129 & 65 & 73 & 1173 \\
\hline
\end{tabular}

(Sumber: Data pemakaian obat di RS Delima Asih Karawang 2019)

Dari 810 obat yang ada di rumah sakit dan dipilih 10 obat generik yang jumlah pemakaian terbanyak. Lalu, selanjutnya akan di dilakukan proses peramalan dengan perhitungan single moving averages. Hasil perhitungan peramalan akan ditambahkan pada perhitungan dalam penentuan obat untuk periode berikutnya dangan metode Material Requirement Planning. Setelah hasil telah didapat lalu dibandingkan hasil penentuan dengan hasil perhitungan dengan model optimasi lingo 11.0

Tabel 2. Perbandingan perhitungan kebutuhan obat dengan Metode MRP dan Model Optimasi

\begin{tabular}{|c|c|c|c|c|c|c|c|c|}
\hline \multirow[b]{2}{*}{ No } & \multirow[b]{2}{*}{ Nama Obat } & \multirow{2}{*}{$\begin{array}{c}\text { Kebut } \\
\text { uhan } \\
\text { Rill }\end{array}$} & \multicolumn{2}{|c|}{$\begin{array}{c}\text { Di Instalasi } \\
\text { farmasi saat ini }\end{array}$} & \multicolumn{2}{|c|}{ Metode MRP } & \multicolumn{2}{|c|}{ Model Optimasi } \\
\hline & & & $\begin{array}{l}\text { Penyedi } \\
\text { aan }\end{array}$ & $\begin{array}{c}\text { Sisa } \\
\text { Persed } \\
\text { iaan }\end{array}$ & $\begin{array}{l}\text { Penyedi } \\
\text { aan }\end{array}$ & $\begin{array}{c}\text { Sisa } \\
\text { Persedi } \\
\text { aan }\end{array}$ & $\begin{array}{l}\text { Penyedi } \\
\text { aan }\end{array}$ & $\begin{array}{c}\text { Sisa } \\
\text { Persediaan }\end{array}$ \\
\hline 1 & $\begin{array}{l}\text { Metformin } 500 \\
M g\end{array}$ & 21348 & 25177 & 3829 & 22200 & 852 & 21408 & 60 \\
\hline 2 & $\begin{array}{l}\text { Paracetamol } \\
500 \mathrm{Mg}\end{array}$ & 18625 & 22962 & 4337 & 19400 & 775 & 18659 & 34 \\
\hline 3 & $\begin{array}{l}\text { Vitamin B } \\
\text { Complex } \\
\text { Asam }\end{array}$ & 7159 & 9452 & 2293 & 7600 & 441 & 7170 & 11 \\
\hline 4 & $\begin{array}{l}\text { Mefenamat } 500 \\
\mathrm{Mg}\end{array}$ & 7683 & 9746 & 2063 & 8000 & 317 & 7714 & 31 \\
\hline 5 & $\begin{array}{l}\text { Dexamethasone } \\
0.5 \mathrm{Mg}\end{array}$ & 4472 & 4711 & 239 & 4700 & 228 & 4506 & 34 \\
\hline 6 & $\begin{array}{l}\text { Ibuprofen } 400 \\
\mathrm{Mg}\end{array}$ & 2849 & 3153 & 304 & 3100 & 251 & 2853 & 4 \\
\hline 7 & $\begin{array}{l}\text { Ethambutol } \\
500 \mathrm{Mg}\end{array}$ & 2569 & 1742 & -827 & 2700 & 131 & 2574 & 5 \\
\hline 8 & $\begin{array}{l}\text { Pyrazinamide } \\
500 \mathrm{Mg}\end{array}$ & 2661 & 2148 & -513 & 2700 & 39 & 2680 & 19 \\
\hline 9 & $\begin{array}{l}\text { Allopurinol } 100 \\
\mathrm{Mg}\end{array}$ & 1807 & 1937 & 130 & 2000 & 193 & 1829 & 22 \\
\hline 10 & $\begin{array}{l}\text { Simvastatin } 20 \\
\mathrm{Mg}\end{array}$ & 540 & 399 & -141 & 570 & 30 & 551 & 11 \\
\hline
\end{tabular}

(Sumber : Hasil perbandingan perhitungan kebutuhan obat)

Dari tabel tersebut diketahui bahwa selisih kebutuhan rill dengan peyediaan oleh rumah sakit terbilang tinggi dan ada beberapa obat mengalami kekurangan seperti Ethanbutol $500 \mathrm{Mg}$ (-827 pcs), Pyrazinamide $500 \mathrm{Mg}$ (-513 pcs), dan Simvastatin $20 \mathrm{Mg}$ (-141 pcs). Hasil perhitungan MRP dan model optimasi tidak mengalami kekurangan dan memenuhi kebutuhan rill namun selisih sisa persediaan diantara dua perhitungan tersebut model opimasi memiliki selisih sisa persediaan lebih sedikit dibandingkan hasil perhitungan MRP.

\section{ANALISIS SENSITIVITAS}

Hasil dari optimasi yang didapat dari sebuah model, dilakukan suatu analisa sensitivitas atau kepekaan terhadap perubahan-perubahan satu atau lebih dari parameter-parameter komponen harga 
pembelian obat, biaya persediaan, dan biaya pemesanan obat. Hal ini di maksudkan untuk menguji kehandalan system/model yang telah dibuat terhadap perubahan-perubahan pembatasnya.

Tabel 3. Sensitivitas perubahan parameter harga pembelian obat terhadap solusi optimal

\begin{tabular}{cccc}
\hline $\begin{array}{c}\text { Perubahan } \\
\text { Parameter } \\
\text { Harga Pembelian }\end{array}$ & $\begin{array}{c}\text { Solusi } \\
\text { Optimal } \\
\text { RP }\end{array}$ & $\begin{array}{c}\text { Perubahan } \\
\text { Biaya } \\
\text { RP }\end{array}$ & $\begin{array}{c}\text { Persentasi } \\
\text { Perubahan }\end{array}$ \\
\hline$-10 \%$ & $11,260,429.00$ & $1,251,298.00$ & $-11 \%$ \\
$-5 \%$ & $11,886,008.00$ & $625,719.00$ & $-5 \%$ \\
Normal & $12,511,727.00$ & - & $0.00 \%$ \\
$5 \%$ & $13,137,446.00$ & $625,719.00$ & $-5 \%$ \\
$10 \%$ & $13,763,025.00$ & $1,251,298.00$ & $-11 \%$ \\
\hline
\end{tabular}

(Sumber : Hasil perhitungan Analisis sensitivitas dengan parameter harga pembelian)

Terlihat pada tabel 3. bahwa disaat harga pembelian obat mengalami penurunan $10 \%$, akan menyebabkan solusi optimal ikut berubah sebanyak $11 \%$ atau mengalami perubahan sebesar Rp. 1.251.298. Hal ini menyebabkan bahwa RS Delima Asih Karawang harus siap mengatisipasi kenaikan atau penurunan harga pembelian obat terhadap total pembelian obat yang didapatkan selama waktu perencanaan.

Tabel 4. Sensitivitas perubahan parameter biaya persediaan obat terhadap solusi optimal

\begin{tabular}{cccc}
\hline $\begin{array}{c}\text { Perubahan } \\
\text { Parameter } \\
\text { Permintaan }\end{array}$ & $\begin{array}{c}\text { Solusi } \\
\text { Optimal } \\
\text { RP }\end{array}$ & $\begin{array}{c}\text { Perubahan } \\
\text { Biaya } \\
\text { RP }\end{array}$ & $\begin{array}{c}\text { Persentasi } \\
\text { Perubahan }\end{array}$ \\
\hline$-10 \%$ & $11,260,429.20$ & $1,251,297.80$ & $-10 \%$ \\
$-5 \%$ & $11,372,821.20$ & $1,138,905.80$ & $-9.1 \%$ \\
Normal & $12,511,727.00$ & - & $0.00 \%$ \\
$5 \%$ & $13,650,632.80$ & $1,138,905.80$ & $9.1 \%$ \\
$10 \%$ & $13,763,024.80$ & $1,251,297.80$ & $10 \%$ \\
\hline
\end{tabular}

(Sumber : Hasil perhitungan Analisis sensitivitas dengan parameter biaya persediaan)

Terlihat pada tabel 4. bahwa disaat jumlah permintaan mengalami penurunan 5\%, akan menyebabkan solusi optimal ikut berubah sebanyak $9.1 \%$ atau mengalami perubahan sebesar Rp. 1.138.905,80. Hal ini menyebabkan bahwa RS Delima Asih Karawang harus siap mengatisipasi kenaikan atau penurunan harga pembelian obat terhadap total pembelian obat yang didapatkan selama waktu perencanaan.

\section{KESIMPULAN}

Berdasarkan pada hasil penelitian yang telah dilakukan maka kesimpulan yang dapat diberikan adalah sebagai berikut:

1. Pada manajemen logistik farmasi di RS Delima Asih Karawang masih terdapat kendala yaitu sering terjadinya kekurangan obat yang menyebabkan rumah sakit mengambil tindakan untuk pembelian obat secara urgensi ke pihak ke -3 dan biaya pembelian obat kepada pihak -3 akan lebih tinggi.

2. Hasil perhitungan peneliti dari 10 obat generik ada 3 obat yang mengalami kekurangan yaitu Ethambutol $500 \mathrm{Mg}$ (-827 pcs), Pyrazinamide $500 \mathrm{Mg}$ (-513 pcs), Simvastatin $20 \mathrm{Mg}$ (-141 pcs) dan sisanya mengalami stagnan. Maka pengendalian persedian obat di RS delima asih karawang belum memenuhi kebutuhan persedian obat. 
3. Dari hasil perhitungan peneliti untuk menen tukan kebutuhan persediaan obat generik di instalasi farmasi dengan metode Material Requirement Planning dan model optimasi dengan Lingo 11.0 tidak mengalami kekurangan dan memenuhi kebutuhan rill Rumah Sakit namun selisih sisa persediaan diantara dua perhitungan tersebut model opimasi memiliki selisih sisa persediaan lebih sedikit dibandingkan hasil perhitungan MRP.

\section{DAFTAR PUSTAKA}

Febriawati, H. (2013). Manajemen Logistik Farmasi Rumah Sakit. Yogyakarta: Gosyen Publishing. Fernando, A., \& Najid, N. (2019). Pilihan Pengendalian Penggunaan Mobil Pribadi dengan Strategi Parkir, ERP dan Transjakarta di Jalan Raya Serpong. JMTS: Jurnal Mitra Teknik Sipil, 2(2), 45-54.

Hakim, I. M., Sari, G. P., \& Ardina, A. E. (2019). Development mathematics model production planning of urea fertilizer to minimize production cost with mixed integer linear programming (MILP). In AIP Conference Proceedings (Vol. 2194, No. 1, p. 020036). AIP Publishing LLC.

Hakim, I. M., \& Ulfah, W. M. (2019). Model Development to Determine Optimal Drugs Inventory in Indonesia Public Health Services. In Proceedings of the 2019 5th International Conference on Industrial and Business Engineering (pp. 28-32).

Martono, R., (2015). Manajemen Logitik Integrasi. Jakarta. PPM Manajemen.

Pinna, R., Carrus, P. P., \& Marras, F. (2015). The drug logistics process an innovative experience. Journal of TQM (27): $214-230$. 